\title{
Communal analysis of the tramway accidentology in France
}

\author{
Adnan Bentama ${ }^{1, *}$, Marine Millot ${ }^{2}$ and Abdellah Khatory ${ }^{1}$ \\ ${ }^{1}$ Laboratory of Production engineering, Energy and Sustainable Development, High School of Technology, Sidi Mohamed Ben Abdellah \\ University, Fez, Route d'Imouzzer BP : 2427, 30 000, Morocco. \\ ${ }^{2}$ CEREMA Méditerranée, DAT-ARTU, Pôle d'activités des Milles, 13593 Aix-en-Provence, cedex 3, France.
}

\begin{abstract}
Introduction: The purpose of this study is to assess the impact of communes size on the number and severity of tram accidents in France. Methodology: For this we calculated the average densities of accidents and serious victims of trams per line kilometer for each class of commune between 2012 and 2014. While adverting to the official data of accidentology and population. Results: The study has shown that almost one third of the municipalities served by the tram have known no accident. The study also showed that the size of the communes is proportional to the accidents density per kilometer of the tram line. The study has also concluded that the density of serious victims per line kilometer is maximum in the communes of average size. Conclusion: To carry out the modal shift toward the urban public transport, it is necessary to deepen our knowledge of the specificities of insecurity of these modes. This study is part of this framework, and made the link between the size of the communes and trams accidentology in France.
\end{abstract}

\section{Introduction}

The tramway is among the transport systems most used in French agglomerations. Indeed, France has 28 tram networks, and as they are among means of public transport with a character, mainly, urban, they are always in interaction with the other road users, this sharing causes, sometimes, accidents which are, in certain cases, serious and very mediatized.

However, few researches were interested in the impacts of public transport in term of road safety [1]. Certain authors explain it by the low percentage of accidents involving public transport, but likewise by the idea that public transport having to contribute to a reduction of the role of the automobile, and this must have a positive event on safety [2]. Others further go, by considering that the public interest in road safety of this mode is not as large as that of the other types of vehicles, the level of safety of public transport being judged like acceptable [3].

Nevertheless, accidents involving trams (all networks), and the resulting casualties are far from being negligible. Indeed, the three years of the study (2012 to 2014) have registered: 438 accidents involving trams which have caused 538 victims.

It is therefore important to take these problems of road safety into account, particularly in the recent context of reintroduction of trams in many French cities. After a period of gradual dismantling of tram networks. But in the past few decades the tramway has made its "comeback" in the heart of French urban centers, playing an important role in urban policies $[4,5]$. In summation to this role, today, it is a central tool of transportation policy, to answer to the rising need for mobility and to guide the governance and the urban functioning by promoting downtown and strengthening territorial cohesion.

The works which were concerned with the aspect of tram safety, established that the tram pose specific safety problems, by direct collisions, for the vulnerable users in particular pedestrians $[6,7,8]$. The tram can intervene, also, indirectly in the genesis process of accidents, for example: A user who crosses the road masked by a tram and hit by a car $[9,10,11,12]$. The publications which examined specificities of tram accidents, in particular the types of involved thirds, show that the tram passengers, the pedestrians and the car passengers are generally the main victims of trams $[13,14]$. Other researchers have interested on the impact of the configuration of public spaces redesigned for trams on road users safety. They conclude that this configurations may have an impact on the occurence of accidents, even when the tram vehicle is not present. $[15,16,17]$

The question that we posed in this paper is linked, primarily, to the congestion at habitat environments of dense and continues nature, which increases the probability of collisions between tramways and the other road users. This approach of the density shows the

\footnotetext{
*Corresponding author: adnan.bentama@usmba.ac.ma
} 
complexity of the reflection. In effect, it carries on the effect of an urbanization more dense, which could reduce the severity of accidents, but conversely could increase their frequency [18]. We are going to try, through this work, to check this assumption for the tram system, and find out what is the impact of the communes size on the accidents number and the victims severity of the tram system in France. To do this, have been calculated the mean densities of accidents and serious victims of trams per line kilometer for each class of commune in France between 2012 and 2014. While adverting to the official data of accidents and population.

\section{Data and methodology}

\subsection{Data}

The work is conducted from the Analysis Balance of Road Traffic Injury Accidents (BAAC), which is a French national basis established by the order forces, from the minutes made as soon as an accident occurs and involving at least one victim. This database includes detailed information on the characteristics and the general circumstances of the accident occurrence (time, places, vehicles and persons involved, etc.). The BAAC files are coupled to GIS software (Geographic Information System) named CONCERTO, this software allows the statistical and cartographic treatment of data.

The duration of the study is spread over three years from 2012 to 2014, this period has recorded, according to the BAAC files, 175440 accidents (all modes) distributed throughout the territory of the Metropolitan France. Our study will treat just tram accidents, and this on all the territory of the Metropolitan France.

\subsection{Methodology}

To deeply analyze the accidents of the tram per communes, and to avoid the comparisons between raw data, we tried to calculate the average density of accidents and victims per $\mathrm{km}$ of tram line for each class of commune. Indeed, we managed to have the layout of tram lines in all the networks of tram in the territory of Metropolitan France, after that we use a communal map of France, Next we could calculate the length of tram networks line by each commune by using MAP-info software, we gathered these communes by size, relating to the population of each commune by using the official statistics of the National Institute of Statistics and Economic Studies (INSEE) of 2013. For accidentology data, CONCERTO enabled us to have the number of accidents and victims of tram in each commune. After having obtained for each commune the tram accidents data, the layout length of tram lines and the population data, we could calculate the average density of tram accidents and the serious victims for each class of commune.

The diagram below recapitulates the methodology used in this work:

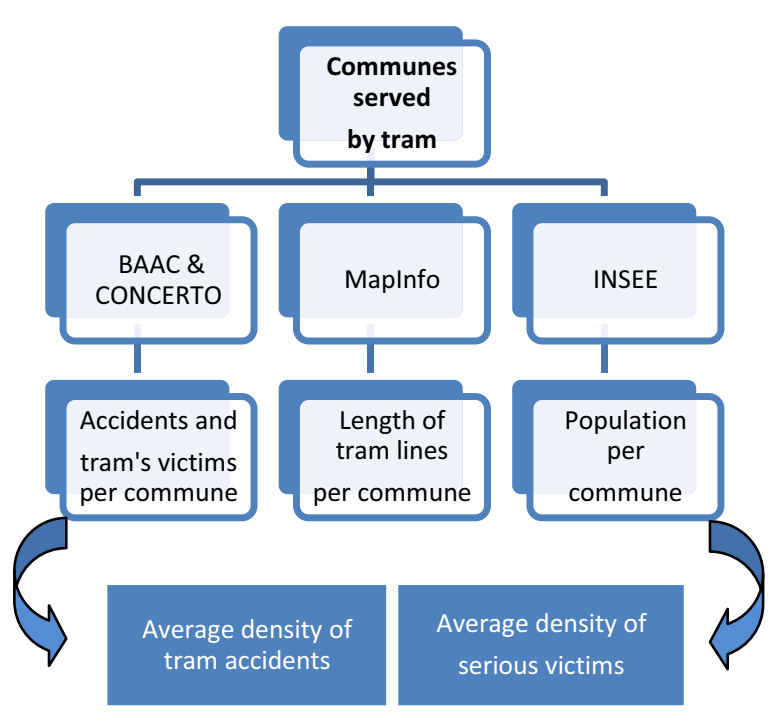

Figure 1. Descriptive diagram of the methodology followed for the analysis of the tram accidents per communes

\section{Results}

\subsection{Communes without accidents}

Table 1 Communes without tram accidents per size in France from 2012 to 2014

\begin{tabular}{|l|c|c|c|c|c|c|}
\hline $\begin{array}{l}\text { Communes } \\
\text { size } \\
\text { (Thousands } \\
\text { inhabitants) }\end{array}$ & $2--5$ & $5--20$ & $\begin{array}{c}20-- \\
50\end{array}$ & $\begin{array}{c}50-- \\
100\end{array}$ & $\begin{array}{c}100-- \\
300\end{array}$ & $>300$ \\
\hline $\begin{array}{l}\text { Number of } \\
\text { communes } \\
\text { served }\end{array}$ & 13 & 52 & 61 & 14 & 20 & 5 \\
\hline $\begin{array}{l}\text { Number of } \\
\text { communes } \\
\text { served without } \\
\text { accidents }\end{array}$ & 6 & 21 & 19 & 4 & 1 & 1 \\
\hline $\begin{array}{l}\text { Percentage of } \\
\text { communes } \\
\text { without } \\
\text { accidents }\end{array}$ & 46,15 & 40,38 & 31,15 & 28,57 & 5,00 & 20,00 \\
\hline
\end{tabular}

On the 165 communes served by the trams in France, 52 communes did not know any accident of tram during the three years of the study (see table 1), they concern in the majority of the communes whose populations lie between 5 and 50 thousand inhabitants.

Note: It is noted that we did not take into account the tram networks which were operational after or during the study period, therefore we took just the operational networks before 2012, i.e. we didn't consider the tram networks of Le Havre, Tours, Besancon, Dijon and Brest. The tram networks included in the study are: Paris, Toulouse, Nice, Lyon, Nantes, Marseilles, Strasbourg, Montpellier, Bordeaux, Lille, Reims, Saint-Etienne, Grenoble, Angers, Mans, Clermont-Ferrand, Orleans, Rouen, Mulhouse, Caen, Nancy, Valenciennes and Douai. 


\subsection{Average densities of accidents and serious victims}

Table 2 Annual average density of the accidents and the serious victims of the tram per kilometer of line according to communes size in France from 2012 to 2014

\begin{tabular}{|c|c|c|c|c|c|}
\hline $\begin{array}{c}\text { Communes } \\
\text { size } \\
\text { (Thousands } \\
\text { inhabitants) }\end{array}$ & $\begin{array}{c}\text { Length of lines } \\
(\mathbf{k m})\end{array}$ & $\begin{array}{c}\text { Number of } \\
\text { accidents }\end{array}$ & $\begin{array}{c}\text { Number of } \\
\text { serious } \\
\text { victims } \\
\text { (Killed + HI) }\end{array}$ & $\begin{array}{c}\text { Annual average density } \\
\text { of the accidents/Km of } \\
\text { line }{ }^{\mathrm{a}}\end{array}$ & $\begin{array}{c}\text { Annual average } \\
\text { density of serious } \\
\text { victims /Km of line }\end{array}$ \\
\hline $2--5$ & 11,23 & 1 & 0 & 0,03 & 0 \\
\hline $5--20$ & 63,28 & 25 & 6 & 0,13 & 0,03 \\
\hline $20--50$ & 131,2 & 70 & 36 & 0,18 & 0,09 \\
\hline $50--100$ & 25,28 & 20 & 10 & 0,26 & 0,13 \\
\hline $100--300$ & 368,7 & 219 & 74 & 0,2 & 0,07 \\
\hline$>300$ & 66,6 & 67 & 15 & 0,34 & 0,08 \\
\hline
\end{tabular}

a densities where the number of accidents or serious victims are under 20 are noted in italic.

The examination of tram accidents in France per class of commune show that communes from 100 to 300 thousand inhabitants record the most tram accidents with 219 accidents, in second position we find communes from 20 to 50 thousands inhabitants and the communes of 300 thousands inhabitants with a very close numbers of accidents (70 and 67 accidents respectively), in third position come communes from 5 to $20 \mathrm{MH}$ and the communes from 50 to $100 \mathrm{MH}$ also with practically the same number of accidents (25 and 20 accidents respectively).

\section{$>$ Average density of tram accidents per class of commune}

The communal analysis of the average density of tram accidents in France, shows that the communes of more than 300 thousand inhabitants which have the ratio more raised. Indeed, this type of commune recorded 0,34 accident for each kilometer of tram line annually. Followed by the communes of 50 to 100 thousand inhabitants, with a ratio of 0,26 accident per kilometer of line per annum. In third place we find communes of 100 to 300 thousand inhabitants with a ratio of 0,2 accident per $\mathrm{km}$ of tram cable. The communes of 20 to 50 thousand inhabitants knew an annual density of tram accidents of 0,18 accident per kilometer of tram line. Lastly comes the communes from 5 to 20 thousand inhabitants with a ratio of 0,13 accident $/ \mathrm{Km}$ of the tram line.

\section{$>$ Average density of serious victims of tram per class of commune}

The analysis of the annual average density of serious victims per class of commune between 2012 and 2014, reveals that the communes of 50 to 100 thousand inhabitants record the highest average of serious victims density, with a ratio of 0,13 serious victim per $\mathrm{km}$ of tram line. Followed by communes of 20 to 50 thousand inhabitants, the communes of more than 300 thousand inhabitants and the communes of 100 to 300 thousand inhabitants with very close ratios, indeed these three commune classes recorded (respectively) 0,09, 0,08 and 0,07 serious victim per $\mathrm{km}$ of line per annum. Lastly come the communes from class 5 to 20 thousand inhabitants with a ratio of 0,03 serious victims per $\mathrm{km}$ of tram line annually. However, it should be noted that it is necessary to interpret these results with precaution, because of the weak frequencies of serious victims in some classes of communes.

\section{Discussion}

This study, which is spread out over three years from 2012 to 2014, aimed to analyze the impact of communes size on tram accidents in France. By evaluating for each class of commune two parameters which are; the average density of tram accidents and the average density of the serious victims per $\mathrm{km}$ of tram line.

The study showed that the communes of 100 to 300 thousand inhabitants which knew the majority of tram accidents in France. But this result cannot enable us to conclude that these communes are overrepresented, because it is necessary to relativise these figures and to cross them with an indicator as the number of kilometers of tram line.

The analysis showed that the communes of big size $(+300$ thousand inhabitants) which record the most raised annual density of accident per $\mathrm{km}$ of tram line. An expected result, which confirms the starting assumption which says that; the densest habitat environments record the most accidents. Because of the strong frequentation of the road by all types of users, what specifically increases the probabilities of collision with the trams. Broadly speaking, it is observed that the annual average of density of the tram accidents per kilometer of line in France is proportional to the size of the communes except communes of 100 to 300 thousand inhabitants. Indeed, this type of commune recorded a density of accident of tram less than the communes of 50 to 100 thousand inhabitants.

Concerning the severity, the study showed that the average density of serious victims caused by tram accidents tram is higher in the communes of 50 to 100 thousand inhabitants, that can be explained by significant 
speeds practiced by tram drivers in the habitat environments of less density. In order to increase the commercial speed of the transport system, which causes serious accidents, because the tram as being a heavy vehicle on rails it requires a long braking distance, in particular if the speed is significant. But it is necessary to take these results with precaution because of the weak numbers of serious victims in some classes of communes. The explanation of speed can be reinforced by the fact that the two types of communes which recorded the most serious victims ( 36 serious victims for communes with 20 to 50 thousand inhabitants and 74 serious victims for communes with 100 to 300 thousand inhabitants) where it is noticed that the communes of size 20 to 50 thousand inhabitants recorded an annual density of serious victims per $\mathrm{km}$ of line of tram higher than that of the communes of 100 to 300 thousand inhabitants.

Some limit must be evoked concerning this study. Firstly, the duration of the study, if the duration was 5 years, that would be better. Especially when we work on a displacement mode, like the tram, which does not make too many accidents. Secondly, weak figures of the data in particular serious victims which poses some problems of statistical significance.

\section{Conclusion}

To conduct the modal transfer towards Urban Public Transport and to decrease the use of the private car, first of all, it is necessary to improve safety of these modes via a deep comprehension of its insecurity specificities. This study aimed to evaluate the impact of the size of communes on tram accidents in France between 2012 and 2014. The study concluded that the size of the communes is proportional to the accidents density per kilometer of tram line. The study also showed that the density of the serious victims per kilometer of line is maximal in the communes of average size.

\section{References}

1. Brenac T., Clabaux N. (2005) The indirect involvement of buses in traffic accident processes. Safety Sci 43:835-843

2. Beer S., Brenac T. (2006). Tramways et sécurité routière, l'expérience des pays germanophones. Transp Environ Circ 190:40-46

3. Cafiso S., Di Graziano A., Pappalardo G. (2013) Road safety issues for bus transport management. Accid Anal Prev 60:324-333

4. Frenay, P. (2005). Le tram, outil en faveur d'une ville durable?: Réflexions tirées d'une comparaison entre quelques villes moyennes françaises et alémaniques ». TEC, 185, 2-8.

5. González, Rubén C. Lois, Miguel Pazos Otón, and Jean-Pierre Wolff. "Le tramway entre politique de transport et outil de réhabilitation urbanistique dans quelques pays européens: Allemagne, Espagne, France et Suisse."Annales de géographie. No. 6. Armand Colin, 2013.
6. Hedelin, A., Björnstig, U., \& Brismar, B. (1996). Trams - a risk factor for pedestrians. Accident Analysis \& Prevention, 28(6), 733-738.

7. Hedelin, A., Bunketorp, O., \& Björnstig, U. (2002). Public transport in metropolitan areas - a danger for unprotected road users. Safety science,40(5), 467477.

8. Isabelle Chalanton et Muriel Jadoul. (2009). « Etude des accidents entre un Tram et un piéton en région de Bruxelles capitale », Institut Belge pour la Sécurité Routière (IBSR).

9. Schnabel, W., Korn, J. (2001). Accident occurence in tram traffic. Proceedings of the international conference 'Road safety on Three Continents' (Pretoria), Staten's VAEG-OCH Transport for sknings instiut, n. 15(A), pp. 516-526.

10. Unger, R., Eder, C., Mayr, J-M., Wernig, J. (2002). Child pedestrian injuries at tram and bus stops. Injury, n.33(6), pp. 485-488.20.

11. Kobi, R. (1990). Sicherheit an Bus-und Tramhaltestellen. Zeitschrift fur Verkehrssicherheit, n. 36(2)

12. Krusyzyna, M., Rychlewski; J. (2013). Influence of approaching tram on behaviour of pedestrians in signalised crosswalks in Poland. Accident Analysis \& Prevention, 55, pp. 185-191.

13. BENTAMA, A., \& KHATORY, A. (2015). Etude statistique des risques du tramway RabatSalé/Maroc.11eme Congrès International de Génie Industriel, Québec les 26-28 octobre 2015.

14. Amon, B. (2002). Unfälle mit Straßenbahnen. In : Hauger, G. (Ed.), Forum Verkehrssystemplanug 2002, Ausgewählte Seminararbeiten, IVS-Schriften Band 15, Institut für Verkehrssystemplanung der TU Wien, Österreichischer Kunst- und Kulturverlag, Wien. Pp. 7-24.

15. Cameron, I. C., Harris, N. J., \& Kehoe, N. J. S. (2001). Tram-related injuries in Sheffield. Injury, 32(4), 275-277.

16. Kobi, R. (1990). Sicherheit an Bus-und Tramhaltestellen. Zeitschrift für Verkehrssicherheit, 36(2).

17. Maitre, E. (2015). Public spaces re-designed for trams in French cities: safety concerns. Advances in Transportation Studies, (37).

18. Millot, M. Etude des liens complexes entre formes urbaines et insécurité routière. Rapport d'étude, CERTU, 2004. 